Article

\title{
External audit quality and clients' corporate governance mechanisms in Nigeria: Any nexus?
}

\author{
Kenny Adedapo Soyemi ${ }^{*}$, Oluwayemisi Victoria Afolabi ${ }^{2}$, and Imoleayo Foyeke Obigbemi ${ }^{3}$ \\ ${ }^{1}$ Department of Accounting, Olabisi Onabanjo University, Ago Iwoye, Nigeria \\ 2 Department of Accounting, Olabisi Onabanjo University, Ago Iwoye, Nigeria. \\ ${ }^{3}$ Department of Accounting, University of Lagos, Akoka, Nigeria. \\ * Correspondence: k.ade.soyemi@gmail.com, +2348033774560
}

Received: 28 December 2020; Accepted: 23 March 2021; Published: 29 March 2021

\begin{abstract}
This study examined the influence of an entity's corporate governance practices on independent external auditor quality, proxied with auditor industry specialization, in Nigeria. The explanatory research design was adopted. Data were sourced from annual reports and accounts of thirty-five (35) quoted non-financial firms for 11 years from 2008 to 2018. After that, panel regression analyses were employed as the estimating technique for the model specified. The empirical results revealed that independent external audit quality is positively influenced by the firm's size but negatively influenced by board Independence and the proportion of female directors on board. Overall, aggregate explanatory variables adopted in this study accounted for $50 \%$ changes in external audit quality. Though these findings largely negate previous ones, they contribute to the extant literature and provide further directions for a future attempt at researching within emerging territories.
\end{abstract}

Keywords: Audit quality; Corporate governance; External audit; Female gender; Industry specialization; Nigeria.

JEL codes: M41; M42

\section{Introduction}

There is no time auditing and accounting profession is not under pressure to redeem its image than now. This apparent loss of confidence is consequent upon the loss of quality services rendered by its principal actors, that is, auditors. Okere et al. (2017) assert that an audited financial statement serves as a tool of information to the stakeholders and shareholders. However, the satisfaction of an audit service depends upon the quality of the audit, which in turn determines the price paid/ payable. According to De Angelo (1981) cited in Soyemi et al. (2020), audit quality is described as the ability to detect misstatement and the willingness to report the irregularities uncovered during an audit engagement. It is a continuum that ranges between very low (poor) and very high (excellent). The audit provides users with a credible financial report by verifying the accounting information prepared by the management. This can only be done if the audit quality is of high quality (Wisdom, et al. 2018). Hence, any demand for audit quality is, by extension, a genuine quest for accurate and reliable financial information upon which the stock exchange operates. An effective corporate governance mechanism is an essential component, generally not only in terms of a nation's economic growth strategy, which is ultimately catered for through entrepreneurial activities of the firms but also particularly in terms of investor confidence. Consequently, there is now an increasing call for tighter corporate governance control and reforms. Good corporate governance practices are essential, especially in developing and emerging nations as it brings about positive change and overall economic 
advancement. There is also evidence to suggest that good corporate governance promotes disclosure, transparency, and accountability, variables which are said to be essential ingredients in promoting the affairs of many developing countries (La Porte, et. al. 2000). However, corporate governance practices require the various factors, tools, mechanisms, and processes required to oversee the overall activities of management incentive with that of the investor for this role to be carried effectively by the management.

Corporate governance and audit quality are Siamese that influence financial reporting processes and the accuracy of the accounting information disclosed. There are copious studies [Ejeagbasi, et. al., (2015), Soyemi, et. al., (2017), Aribaba \& Ahmodu (2017), Soyemi (2020)] relating corporate governance mechanisms to audit quality, with each studies having its unique findings. Though these findings are largely consistent with one another, there are a few inconsistencies noticeable. Besides, different proxies have been adopted to measure audit quality, among which audit fees and auditor are prominent. Industry specialization is another measure yet to be explored. Consequently, this study sought to examine the influence of corporate governance on audit quality, proxied with using Industry specialization among quoted non-financial firms in Nigeria. Studies that have done this are very scanty, especially in emerging economies. Nigeria provides a rich institutional context within which this type of study may be undertaken. Her corporate governance landscape is largely evolving as family-attachment is still prevalent, gender inequality on board appointments, the lean board size, and the presence of a few financial literates on audit committees. Besides, the audit industry is largely populated with the international big4 audit firms in the light of very many indigenous professional practice firms spread across the country. It is little or no litigation risk as court cases against auditors are very scarce, perhaps, an out-of-court settlement may have been the order of the day. Furthermore, the Financial Reporting Council of Nigeria (FRCN) as an industry watchdog in charge of financial reporting processes and incidental matters share part of the blame. This agency may be too overwhelmed with its functions and duties. Unlike their activities in the wake of their establishment, for example, identification and publication of financial infractions and corporate governance breaches among entities like Alliance and General Insurance Limited/ Alliance and General Life Assurance Plc in its 2010 annual audited accounts, Stanbic IBTC Holding Plc on its accounts for years ended December 2013 and 2014, etc., virtually nothing is heard of the agency. This is despite the existence of fines and penalties in FRC's annual accounts and audited accounts (2018 $=\$ 202.1$ million, $2017=\$ 325$ million, $2016=\$ 991.75$ million, $2015=\$ 21.015$ million, $2014=\$ 151.365$ million). Besides the financial sector, there are noticeable corporate governance breaches in non-financial sectors as well. Cadbury Nigeria Plc, Oando, and a host of others are prominent examples. In Cadbury's case, the Securities and Exchange Commission (SEC) imposed a fine of $\$ 21.2$ million for overstating the company's accounts which were traceable to the duo of the Chief Executive and financial executive director in a quest deceitfully achieve a target growth. Concerning Oando, SEC handed down varying sanctions ranging from monetary fines to suspension of key management executives as a result of corporate governance violations such as poor board oversight, irregular approval of directors' remunerations, and abuses including false disclosures, internal control failures, etc. The auditors in both cases were sanctioned for providing poor cum low audit quality services. Consequently, research of this nature on developing economies like Nigeria is not only desirable but necessary in other to provide empirical evidence towards explaining the influence of corporate governance mechanisms on audit quality.

The rest of this paper progresses as follows: next section, that is, Section 2 reviews pieces of literature related to the subject matter, Sections 3 and 4 discuss methodology and empirical results respectively, while Section 5 concludes the paper. 


\section{Literature Review}

\subsection{Audit Quality}

Audit quality has continuously escaped an exact definition that may be universally applied in all circumstances. Dresdner \& Fischer (2020) while explaining this opines that it (audit quality) is more of a 'concept' rather than a 'term'. Knechel (2016) posits that it is hardly observable but may be measured. Christensen, et. al. (2016) describe the concept from two (2) perspectives, namely auditors and investors, each listing preferred attributes before an audit engagement can be christened as qualitative. These among others are compliance with GAAS, accurate and reliable financial statements, efficient audit planning, etc (auditors); training skills, competency, independence, etc (investors). However, one of the most frequently used definition is that offered by DeAngelo (1981) cited in Soyemi, et. al. (2017) as 'the market-assessed joint probability that a given auditor will both (a) discover a breach in the client's accounting system and (b) report the breach'. While the latter is referred to as auditor expertise, the latter is known as auditor independence. Whereas a generally acceptable definition seems difficult, there is a consensus on measures used in extant literature. According to Gana \& Lajmi (2011) cited in Riguen, et. al. (2018) these measures among others include auditor size (auditor-type), audit opinion, audit lag, audit specialization, audit tenure, and audit experience. The choice of audit specialization as a measure of audit quality for this study is a result of the paucity of studies where such was adopted. Therefore, there is a growing trend among scholars [(Sari, 2018); (Badawy \& Aly, 2018); (El-Deeb \& Hegazy, 2016)] on the use of audit specialization alongside its association with the provision of excellent and quality audit services to clients. Unlike other measures of audit quality, audit specialization adopts the market share of auditors' industry specialists using total assets as the basis.

Audit quality is a basic ingredient in enhancing the credibility of financial statements to users of accounting information (Wallace, 2004). The audit function plays a crucial role not only to monitor managerial actions but also to create a better information environment as well as providing a secondary source of assurance against corporate failures. Nasrudin, et. al. (2017) identify three (3) external enforcers of good governance namely auditors, corporate advisers, and regulators. Therefore, auditors are required to give appropriate assurance through their opinions on whether the firms' annual accounts have been properly drawn up and in compliance with approved standards, and if they portray a true and fair view of the firms' affairs. The auditor is said to carry out the corporate governance role to monitor the firm's financial reporting process and they often serve as a watchdog.

\subsection{Corporate Governance}

La Porte, et al (2000) describe corporate governance as structure and processes by which business and company affairs are controlled and managed, to establish a long-term value by enhancing the performances of the firm and accountability while considering the interest of their shareholders. It is said to be effective if it can provide a structure that can work for the benefit of stakeholders through strict adherence to ethical standards and practices. Thus, it is the structure through which the objectives of the company are set and the means of attaining those objectives and monitoring performance are determined.

Corporate governance is effective in monitoring whether the outcomes are following plans and motivating the organization to be fully informed to maintain the activity of the organization. Strong corporate governance requires an effective board. The board is responsible for determining the company's aims and objectives and putting strategic plans and policies needed to fulfill those aims in place. The role of the board also involves leading and controlling the company and providing entrepreneurial leadership of the company within a framework of prudent and effective controls which allows for appropriate assessment and management of risk. According to Lincoln \& Adedoyin (2012), there are four (4) main functions of the board, namely (a) set the goal for corporations (b) appoint corporate chief executives (c) oversight of management plans for the acquisition; and (d) organization of financial and human resources towards the attainment of the corporation's goals and 
final review of the corporation's progress towards attaining its goals. This is in tandem with the view expressed by Epstein \& Roy (2006) which posit that the Board of Directors must provide superior strategic guidance to ensure the company's corporate governance and an effective board ensures growth and prosperity, accountability of the company to its stakeholders and ensure the creation of highly qualified executive teams tasked with managing the company. For a board to be effective, it must be independent, that is, there should be a separation of ownership from management and avoidance of been unduly influenced by vested interest and to be free from any constraint that would prevent a correct course of action to be taken. Although it is evidenced that the presence of an outside director within a board is not ideal although (He, et. al. 2013), they can be more effective in the area of monitoring and management and enhancing financial reporting quality. A board with independent members is objective in decision making and it improves the monitoring and controlling activities over management. Also, the board is less likely to be effective and functional in financial reporting oversight due to the coordination and communication problems among board members in the large boards. Thus, a small board may be more effective and functional in performing its duties (Jensen, 1993).

\subsection{Empirical Review}

A few scholarly works have been reviewed in this section. They are categorized into developed, developing economies as well as studies conducted within the Nigerian context.

\subsubsection{Evidence from Developed Economies}

Quick, et. al. (2018) examine the effect of corporate governance mechanisms on audit quality (proxied with auditor choice between big4 and non-big4 binary variable) among listed German firms. Secondary data comprising of 432 datasets for 5 years covering 2010-2014 was collected from annual reports and accounts. A logistic regression analysis was adopted to estimate the model specified for the study. While board size and frequency of audit committee meetings displayed a positive and significant relationship with auditor choice, frequency of board meetings and compliance with code of corporate governance exhibited negative and significant association. In the United States, Lai, et. al. (2017) examines the influence of the female gender on the board of directors and audit committees on audit quality (proxied with industry specialist auditors and audit fees). Data culminating into 9,392 firm-year observations for 11 years spanning 2001 to 2011. Multivariate OLS was adopted to estimate the models stated for the study. Findings from this study provide empirical evidence that female diversity on the board and audit committee positively and significantly influence the selection of industry specialist auditors and payment of higher audit fees.

Similarly, Ghafran \& O'Sullivan (2017) conducts a comprehensive study on the effect of audit committee attributes on audit quality among FTSE350 companies in the United Kingdom. The study was based on 991 firm/year observations as the final sample comprises of a range between 246 (2007) and 249 (2010) as some companies were omitted owing to missing values. Data were gathered from various secondary sources ranging from companies' websites and DataStream. Findings from this study also support the hypothesis of a direct relationship between corporate governance and audit quality. Specifically, audit committee expertise shows a positive and significant relationship with audit quality. However, this relationship was driven by non-accounting expertise. Drogalas, et. al. (2016) investigates the influence of governance mechanisms on internal control processes, a proxy for audit quality among companies listed on the Athens Stock Exchange. A survey methodology was adopted with a questionnaire designed and administered. Thereafter, multiple regression analysis was conducted to estimate the model for the study. The study provides evidence to support the influence of corporate governance attributes and audit quality as they exhibited a positive and significant association with audit quality. Piot (2013) evaluates the impact of agency cost conflict (proxied with ownership diffusion and high Investment-Opportunity-Set) on audit quality (proxied with big6/nonbig6, major national and local auditors) among listed French firms. The final sample of companies listed on the first and second tier of the Paris Exchange comprises 285 observations. Findings from the study indicate a strong direct relationship between high Investment-Opportunity-Set and audit 
quality. There was no empirical evidential backing to the ownership-audit quality nexus among Fresh firms.

\subsubsection{Evidence from Developing Economies}

Widani \& Bernawati (2020) examines the influence of corporate governance practices on audit quality as well as examining the moderating role of ownership concentration in the relationship thereof among 129 Indonesian quoted manufacturing companies for 2 years (2017-2018) were gathered from the selected companies' annual reports and accounts. Thereafter, moderated regression analysis was deployed as the estimating technique. Secondary data from 129 quoted manufacturing companies for 2 years (2017-2018) were gathered from the selected companies' annual reports and accounts. Thereafter, moderated regression analysis was deployed as the estimating technique. Results reveal no empirical evidence to support either the influence of corporate governance practices on audit quality or moderating role of ownership concentration, as none of the explanatory variables were significant. Sarhan, et. al. (2019) analyze the effect of corporate governance mechanisms (measured at country and firm levels) on audit quality (proxied with auditor choice and audit fees) among Middle Eastern and Northern African (MENA) countries. The final sample comprises 20 non-financial firms listed on national stock exchanges of Egypt, Jordan, Oman, Saudi Arabia, and UAE for 6 years from 2009 to 2014. This amounted to 600 data/firm observations. The stratified sampling technique was adopted. Both logit and OLS regression models were specified and estimated as appropriate. Findings from this study revealed an association between country-level corporate governance practices and audit quality. Board independence was positive and significantly related to engagement of big4 audit firms and payment of higher audit fees. Both logit and OLS regression models specified were significant and predicted 36\% (pseudo R2) and $72 \%$ of variations in audit quality across the MENA territories.

Further, Khudhair, et. al. (2019) examines the impact of corporate governance (internal and external) mechanism on audit quality (binary big4 versus non-big4) among listed non-financial Iraqi firms. Using firm/year observations of 168 comprising 42 Iraqi firms for 4 years (2014-2017), a logit model was specified and estimated as appropriate. Board size and audit committee independence displayed a positive and significant association with audit quality. Firm size and leverage (control variables) also exhibited a similar relationship with audit quality. With a pseudo R2 value of $25 \%$, the specified model was significant. AlQadasi \& Abidin (2018) examine the twin-objective of substitute versus the complementary role of internal corporate governance mechanisms and concentrated ownership on audit quality and whether these relationships are moderated by concentrated ownership. Secondary data composed of 544 listed non-financial Malaysian firms for 4 years covering 2009-2012 gathered from annual reports and Thomson financial DataStream resident in the library of University Utara Malaysia was analyzed using OLS with standard robust errors. This period tallies with a massive reform era within the auditing environment. While there is strong evidence supporting a positive and significant influence of internal corporate governance and audit quality, ownership concentration exhibited a negative and significant association with demand for audit services, indicative of a complementary role thereof. Also, ownership concentration does not moderate this association in any way. Overall, the explanatory variables explain $68 \%$ of changes in audit quality. Suryanto, Thalassinos \& Thalassinos (2017) provides empirical evidence as to the influence of corporate governance on audit quality among listed Indonesian firms. Secondary data from 121 listed non-financial firms for 5 years from 2012-2016 were gathered from annual accounts of selected firms. Thereafter, the logit model specified was estimated using multiple regression. While board size and audit committee independence exhibited negative and significant association, audit committee expertise, firm size, and leverage (control variables) maintained a positive and significant relationship with audit quality. The model predicted $42 \%$ (pseudo R2) variations in demand for extensive services.

Using 73 developing countries across Africa, Asia, Europe, South America (excluding China, East Timor, and Trinidad \& Tobago), Beisland, Mersland, \& Strøm (2015) investigates audit quality (proxied with big4 versus non-big4 binary and presence of internal control) and governance mechanisms 
(internal and external) among microfinance institutions (non-profit and otherwise). The probit model specified for the study was estimated using multivariate OLS for unequal/unbalanced 1,616 firms/year observations comprising 379 microfinance institutions for 9 years spanning from 2001 to 2009. Using big4/non-big4 dichotomous variable as a proxy for audit quality, results reveal only CEO/Chair duality as negatively and significantly related with the model explaining $31 \%$ of variations in audit quality. Unlike, big4/non-big4 dichotomous variable, governance practices among studied MFBs appear positive and significantly related to audit quality. Both models are correctly specified explaining $31 \%$ and $20 \%$ (pseudo R2) of variations in audit quality respectively. Similar to other studies, Gajevszky, A. (2014) examines the effect of corporate governance attributes on audit quality among Romanian listed firms. Listed non-financial tiers I, II, and III firms on the Bucharest Stock Exchange constitute the sample size for 5 years from 2008-2012. Thereafter, OLS was adopted as the estimating technique. A positive and significant relationship exists between the existence of audit committees while a negative and significant association occurs between CEO duality and institutional investors and audit quality. However, none of the control variables are related to audit quality. The model accounts for $34 \%$ differences in audit quality.

Shan (2014) examines the influence of internal corporate governance on audit quality among Chinese firms. 443 data/firm observations for 4 years (2002-2005) were gathered and analyzed through OLS. A positive and significant relationship exists between foreign ownership and the number of professional supervisors while a negative and significant association occurs between board size and audit quality. Soliman \& Abdel Salam (2013) investigates the influence of corporate governance practices on audit quality among the top 50 most active companies on the Egyptian Stock Exchange. Data on corporate governance measures such as board independence, CEO duality, audit committees, institutional investors, and managerial ownership were gathered for 3 years from 2007-2009. The dependent variable is binary, a logistic regression model was specified and estimated using OLS. With an adjusted R2 OF $84 \%$, board independence and audit committee display positive and statistically significant association while CEO duality exhibited a negative and significant relationship with the audit committee. However, there is no evidence linking institutional investors and managerial ownership with audit quality.

\subsubsection{Evidence from Nigeria}

Saidu, \& Aifuwa (2020) examines board characteristics (board independence, size, and female representation) as they affect audit quality among quoted manufacturing companies. A binary probit regression model was specified and estimated accordingly. Data comprises 53 quoted manufacturing companies for 10 years from 2009-2018. Findings reveal that only board size appears positive and statistically significant in influencing audit quality. Further, female presence on the board does not play any moderating role in the relationship between board attributes and audit quality. In summary, the study concluded that board attributes do not influence audit quality. Ogoun \& Perelayefa (2020) analyses the impact of board independence, proxied with CEO Duality on fostering excellent audit quality. Similar to other extant literature, secondary data that are panel in nature were collected from 71 non-financial firms from 2008-2015. A logit model was adopted as audit quality was proxied with big4 versus non-big4 dichotomy variable. Overall, the model accounts for only $6 \%$ of changes in audit quality with board independence displaying a negative and significant influence on demand for audit services. Soyemi (2020) provides empirical evidence as to the influence of internal corporate governance practices on the choice of the external auditor, proxied with the big4 versus non-big4 dichotomous variable. The specified model was estimated using a logistic regression on 27 purposely selected quoted non-financial firms for 7 years covering 2011-2017, culminating into 189 firms/year observations. Of the internal corporate governance variables selected, only board independence exhibited a positive and significant relationship with demand for big4 auditors. A control variable, that is, firm size displayed similar results.

Using audit fees as a proxy for audit quality, Mustapha, et. al. (2019) evaluates relationships among board independence, frequency of meeting, and presence of female gender on the board 
thereof. Data were collected on 63 randomly selected quoted non-financial firms for 6 years running from 2012-2017. Multiple regression analysis was adopted to estimate the linear model specified for the study. The relationships between the frequency of board meetings and the presence of female directors on the board are positive and significant about audit fees. Soyemi, Sanyaolu, \& Salawu (2019) examines to what extent would corporate governance practices influence audit quality. Data were gathered from annual reports and audited accounts of 21 non-financial firms for 6 years covering 20122017. Thereafter, OLS regression was adopted to estimate the specified model. Hinged on the fixed effect regression estimates, the results reveal that board and audit committee independence exhibited a negative and significant relationship with audit report lag, invariably, audit quality. Overall, the model explained $61 \%$ of total changes in audit report lag. Asiriuwa, Aronmwan, Uwuigbe, \& Uwuigbe (2018) examines the influence of audit committee attributes on audit quality among quoted nonfinancial firms. Data from a sample of 50 firms for 3 years, from 2012 to 2014 were collected from annual reports and accounts. Thereafter, the logit model was estimated to determine the extent and significance of the relationship between audit quality and audit committees. Of the three (3) selected attributes of the audit committee, only the size of the audit committee displays a positive and significant relationship with the demand for audit services.

Aribaba, \& Ahmodu (2017) analyses the effect of corporate governance measures (board diligence, board independence, ownership concentration, and managerial ownership) on audit quality, represented by audit fees. Secondary data were collected on 25 quoted non-financial firms for 6 years from 2011 to 2016 using their audited financial statement. The panel OLS was adopted to estimate the model for the study. Results reveal a positive and significant relationship between board diligence and audit quality. Other measures of corporate governance do not display any significant association. Further, the specified model succeeded in explaining $59 \%$ of differences in audit quality. Focusing on the banking industry, Ejeagbasi, et. al. (2015) investigates the effects of corporate governance on audit quality, represented by the big4 versus non-big 4 binary variable. Secondary data were gathered from annual reports and accounts of 11 commercial banks for 7 years (2007-2014). Thereafter, analysis was conducted using linear correlation with correlation coefficients taken as a measure of association. Except for board composition, all other explanatory variables exhibited a positive and significant association with audit quality. Overall, 38\% variations in audit fees were owing to selected aggregates of explanatory variables for this study. Chukwunedu \& Ogochukwu (2014) investigates perceptions of board effectiveness and their influence on audit quality. The survey method was adopted as a sample size comprised of 52 of 300 chartered accountants that were expected in the Eastern zonal accountants' conference in 2013. Thereafter, a ranking approach and ANOVA were deployed. Overall, the paper provides empirical evidence on the positive and significant influence of board attributes effectiveness and audit quality with board diligence ranking high towards improving board effectiveness.

\subsection{Theoretical Framework}

The applicable theory for this work is the agency theory. The agency theory is most relevant to this study due to its link with corporate governance and audit. The board of directors is principal agents while owners, who have contributed resources, are principals. Therefore, focusing on board attributes such as size, independence, gender alongside its committees and their relationship with audit quality, as done in this study justifies the adoption of agency theory. Audit(or) is a principal tool adopted by the principal to assist in reducing information asymmetry problems arising from the agency theory. Prior studies have extensively used the agency theory to explain the need for a contractual relationship between shareholders and management. [Soyemi, Olufemi \& Adeyemi (2020), Wisdom, Love et al (2018) Nasrudin, Mohamed \& Shafie (2017)]. The agency theory provides a link with corporate governance that points that separation of ownership and control and widespread ownership. This agent possesses the required professional skills in the area of managing the corporation. Jensen and Meckling (1976) describe agency theory as a legal fiction that serves as the link for the contractual relationship between agent and principal whose aim is to maximize their interest. 
The activities of the firm arise as it delegates its activities and on mandate relationship which leads to principal and agent problem and information asymmetry. The need for this theory arises from the conflict between shareholders and managers (Watts \& Zimmerman 1983) as a result of exertive conduct and opportunistic behavior displayed by the agent. The theory state that once principal assigns duties to the agents, they often have a problem controlling them because there seems to be a conflict of interest, where the goal of the agent differs from that of the shareholders and because the agents are better informed about the capacity and activities than the principal. Agency theory focuses on the ways principal tries to mitigate the control problem by selecting forms of monitoring and controlling their actions. A principal way is an audit, where an independent external auditor is engaged to report on the credibility of financials rendered by the management

\section{Data and Methods}

This study adopted an ex-post facto research design since it is based on a quantitative description of historical financial data. The population for this study includes 63 non-financial firms listed on the Nigerian stock exchange that are active and whose stocks are being traded and renders annually published report as of 31st December 2018. Thirty-five 35 firms, representing 56\%, were chosen as samples for 11 years from 2008-2018 culminating in a total observation of three hundred and eightyfive (385) firm/year dataset.

\subsection{Measurement of Variables}

Table 1 provides the definition and measurement of the dependent and independent variables as used in the study.

Table 1. Measurement of Variables

\begin{tabular}{|c|c|c|c|}
\hline \multicolumn{4}{|c|}{ Dependent Variable (Audit Quality) } \\
\hline Variable & Definition & Measurement & Source(s) \\
\hline IS & $\begin{array}{c}\text { Industry } \\
\text { Specialization }\end{array}$ & $\begin{array}{l}\text { The market share of the audit firm } \\
\text { measured by total assets divided by } \\
\text { the total asset of firms in a specific } \\
\text { industry multiplied by } 100\end{array}$ & Lai, et. al. (2017), Akhidime (2015) \\
\hline \multicolumn{4}{|c|}{ Independent Variables (Corporate Governance) } \\
\hline Variables & Definition & Measurement & Source(s) \\
\hline BS & Board Size & $\begin{array}{l}\text { The total number of board members } \\
\text { on the board }\end{array}$ & $\begin{array}{l}\text { Saidu, \& Aifuwa (2020), Khudhair, } \\
\text { Al-Zubaidi, \& Raji (2019), Suryanto, } \\
\text { Thalassinos \& Thalassinos (2017), } \\
\text { Beisland, Mersland, \& Strøm (2015). }\end{array}$ \\
\hline BI & $\begin{array}{c}\text { Board } \\
\text { Independence }\end{array}$ & $\begin{array}{l}\text { Measured as the total number of } \\
\text { independent and/or non-executive } \\
\text { director divided by the total board } \\
\text { size }\end{array}$ & $\begin{array}{c}\text { Ogoun \& Perelayefa (2020), Sarhan, } \\
\text { Ntim, \& Al-Najjar (2019), Ghafran \& } \\
\text { O'Sullivan (2017) }\end{array}$ \\
\hline SAC & $\begin{array}{l}\text { Size of Audit } \\
\text { Committee }\end{array}$ & $\begin{array}{l}\text { The total number of members in the } \\
\text { audit committee }\end{array}$ & \\
\hline $\mathrm{IO}$ & $\begin{array}{l}\text { Institutional } \\
\text { Ownership }\end{array}$ & $\begin{array}{l}\text { A dichotomous variable that takes } \\
\text { the value of } 1 \text { if the largest } \\
\text { shareholder is an institution and } 0 \text { if } \\
\text { otherwise }\end{array}$ & $\begin{array}{l}\text { Soyemi (2020), AlQadasi \& Abidin } \\
\text { (2018), Gajevszky, A. (2014) }\end{array}$ \\
\hline SGS & $\begin{array}{c}\text { Share of } \\
\text { gender on board }\end{array}$ & $\begin{array}{c}\text { The total number of female directors } \\
\text { on the board divided by the board } \\
\text { size }\end{array}$ & $\begin{array}{l}\text { Quick, et. al. (2018), Lai, Srinidhi, } \\
\text { Gul \& Tsui, (2017) }\end{array}$ \\
\hline
\end{tabular}




\begin{tabular}{cccc}
\hline LEV & Leverage & $\begin{array}{c}\text { The ratio of total liabilities of the firm } \\
\text { to total assets }\end{array}$ & $\begin{array}{c}\text { Soyemi (2020), Khudhair, Al- } \\
\text { Zubaidi, \& Raji (2019), Suryanto, } \\
\text { Thalassinos \& Thalassinos (2017), } \\
\text { Akhidime (2015) }\end{array}$ \\
\hline TA & Total Asset & The natural logarithm of a firm's total \\
& assets & $\begin{array}{c}\text { Soyemi (2020), Khudhair, Al- } \\
\text { Zubaidi, \& Raji (2019), Suryanto, } \\
\text { Thalassinos \& Thalassinos (2017) }\end{array}$ \\
\hline
\end{tabular}

\subsection{Model Specification}

The study model was adapted from Karaibrahimglu (2013). Unlike that of Karaibrahimglu (2013), this study uses 5 measures of corporate governance and 2 control variables to assess their impact on the industry specialization dimension of auditor choice of non-financial firms in Nigeria. The functional representation form of the linear relationship between the independent and dependent variable can be presented as follows:

ISit $=\beta 0+\beta 1$ BSIZEit $+\beta 2$ BINDit $+\beta 3$ IOit $+\beta 4$ SACit $+\beta 5$ SGSit $+\beta 6$ LEVit $+\beta 7$ TAit $+£$ it 1.1

Where: IS = Industry Specialisation

BSIZE $=$ Board size

BIND $=$ Board independence

IO = Institutional ownership

SAC $\quad=$ Size audit committee

SGS $\quad=$ Share of gender on a supervisory board role.

TA $\quad=$ Total assets

LEV = Leverage

$£ \quad=$ Error term

The panel OLS is the estimation technique that is adopted to estimate the model as specified for this study. The regression was conducted for pooled, fixed, and random effects, and formal test criteria were carried out for selecting the estimates upon which this present study was based.

\section{Results}

This section presents the descriptive statistics for continuous variables of the data used for the study. The results of the descriptive statistics are presented in table 2.

Table 2. Descriptive Statistics for Continuous Variables

\begin{tabular}{ccccc}
\hline Variables & Mean & Std. Dev. & Min. & Max. \\
\hline IS & 17.2130 & 23.7366 & 0.18 & 100 \\
\hline BSIZE & 9.1220 & 2.4448 & 3 & 80 \\
\hline BIND & 17.5571 & 23.9737 & 0 & 8 \\
\hline SAC & 5.6623 & 0.9102 & 2 & 91 \\
\hline SGS & 12.3977 & 14.4947 & 0 & 20.0438 \\
\hline LEV & 2.1705 & 2.1077 & 0.5210 & N645,000,000 \\
\hline FSIZE & N63,700,000 & $111,000,000$ & N585,298 \\
\hline
\end{tabular}

Source: Data Analysis Output (Stata 15)

The average value for the Industry Specialization (IS) is $17.21 \%$, with a standard deviation of 23.73, with 0.18 and 100 as the respective minimum and maximum values. The board size displays an 
average of 9 members, with a standard deviation of 2.44, while the minimum and maximum values stood at 3 and 17 respectively. This reveals that among sampled non-financial firms, the average number of directors on board is 9 which ranges from 3 to 17 directors. In a similar vein, $18 \%$ or 2 directors were independent, non-executive with a standard deviation of 23.97 and a range between $0 \%$ (minimum) and $80 \%$ (maximum). The total number of members comprising the audit committee (SAC) amounts to 6, with a standard deviation of 0.9102 , while having 2 and 8 as the minimum and maximum values respectively. The Share of Gender on Board (SGS) has an average mean of 12 percent, with a standard deviation of 14.4947 , while $0 \%$ and $91 \%$ are the respective minima and maximum values. These findings support previous studies from Lincoln \& Adedoyin (2012). This may be as a result of so many factors such as traditional and cultural factors.

As regards the control variables, leverage (LEV) displays an average value of $2 \%$ with a standard deviation of 2.108 . It ranges from $5 \%$ and $20 \%$ being the respective minimum and maximum values. The firm size, proxied with total assets (TA) displays a mean value of N63.7 million, with a standard deviation of 111, 000,000 while having N585,298 and N645 million as the minimum and maximum values respectively. In other to reduce the magnitude and huge range noticeable in the dependent variable (industry specialization) and total assets (a measure of firm size), the natural logarithms were computed and adopted for multivariate regression purposes. Table 3 further presents the descriptive statistics for the only categorical variable, which is institutional ownership, used in this study.

Table 3. Descriptive Statistics for Categorical Variable

\begin{tabular}{ccccc}
\hline Institutional Ownership (INST_OW) & Frequency & $\mathbf{\%}$ & Cum. $\%$ \\
\hline 0 & 50 & 12.99 & 12.99 \\
\hline 1 & 335 & 87.01 & 100.00 \\
\hline \multicolumn{4}{c}{ Source: Data Analysis Output (Stata 15) }
\end{tabular}

Of the 385 data/firm observations, $335(87 \%)$ show the presence of institutional owners while institutional investors were absent in 50 observations (13\%). According to DeFond et al., (2000), this circumstance of monopolist shareholding has essentially usually led to poor corporate governance practices and raised serious concerns by investors, professionals, regulators, and the public. This is typical of the corporate environment in Nigeria, as reported by Soyemi, et al (2020).

\subsection{Correlation Analysis}

Table 4 displays the correlation matrix among variables used in the study. First is the association of industry specialization and independent variables and second, the association among independent variables.

Table 4. Correlation Matrix

\begin{tabular}{|c|c|c|c|c|c|c|c|c|}
\hline & $\ln I S$ & BS & BI & SAC & SGS & IO & LEV & $\ln T A$ \\
\hline LnIS & 1.000 & & & & & & & \\
\hline BS & 0.281 & 1.000 & & & & & & \\
\hline BI & -0.016 & 0.132 & 1.000 & & & & & \\
\hline SAC & 0.141 & 0.441 & 0.155 & 1.000 & & & & \\
\hline SGS & 0.016 & 0.122 & -0.090 & 0.143 & 1.000 & & & \\
\hline IO & 0.052 & 0.092 & -0.132 & 0.061 & 0.077 & 1.000 & & \\
\hline LEV & -0.205 & 0.045 & -0.044 & 0.088 & -0.117 & 0.032 & 1.000 & \\
\hline $\ln T A$ & 0.649 & 0.412 & 0.052 & 0.182 & 0.058 & 0.178 & -0.153 & 1.000 \\
\hline
\end{tabular}

From table 4, it is evidenced that board size (BS) is positively correlated with industry specialization at a $1 \%$ level of significance. Board Independence (BI) is negatively correlated with industry specialization but not significant. The size of the audit committee (SAC) is positively 
correlated with industry specialization at a $1 \%$ level of significance. Share of gender on board (SGS) is positively correlated with industry specialization at a $5 \%$ level of significance. Institutional ownership (IO) is positively correlated with industry specialization, but not significant. Leverage (LEV) is negatively correlated with industry specialization at a $1 \%$ level of significance. Total assets (TA) are positively correlated with industry specialization at a $1 \%$ level of significance. Besides, none of the correlation coefficients are large enough to pose a multicollinearity problem.

\subsection{Variance Inflation Factor (VIF)}

Further, Table 5 presents the Variance Inflation Factor (VIF) for explanatory variables used in this study. This is to corroborate the absence of the incidence of multicollinearity, as seen in table 4 .

Table 5. VIF Estimates

\begin{tabular}{ccc}
\hline Variable & VIF & 1/VIF \\
\hline BS & 1.47 & 0.679 \\
\hline SAC & 1.29 & 0.777 \\
\hline LnTA & 1.28 & 0.779 \\
\hline LEV & 1.07 & 0.931 \\
\hline BI & 1.07 & 0.933 \\
\hline SGS & 1.06 & 0.939 \\
\hline IO & 1.06 & 0.941 \\
\hline Mean VIF & 1.19 & \\
\hline
\end{tabular}

Source: Data Analysis Output (Stata 15)

With an average VIF value of 1.19 and VIF for individual explanatory variables ranging from 1.06 (IO) to 1.47 (BS), alongside TV also between 0.679 (minimum) and 0.941 (maximum), it is further confirmed that there are no multicollinearity problems among the independent variables.

\subsection{Multivariate Regression Analyses}

Table 6 presents the estimates for the multivariate regression analyses for pooled as well as fixed and random effects.

Table 6. Multivariate Regression Results for Pooled, Fixed, and Random Effects OLS

\begin{tabular}{|c|c|c|c|c|c|c|}
\hline \multirow{2}{*}{$\begin{array}{l}\text { Variables } \\
\text { DV }=\ln I S\end{array}$} & \multicolumn{2}{|c|}{ Pooled } & \multicolumn{2}{|c|}{ Random } & \multicolumn{2}{|c|}{ Fixed } \\
\hline & Coef. & $\mathrm{t}$-value & Coef. & z-value & Coef. & t-value \\
\hline BS & 0.177 & 0.62 & -0.011 & -0.51 & -0.018 & -0.80 \\
\hline $\mathrm{BI}$ & -0.005 & $-1.98^{* * *}$ & -0.005 & $-2.22^{* *}$ & -0.005 & $-2.18^{* *}$ \\
\hline SAC & 0.079 & 1.10 & 0.104 & 1.36 & 0.097 & 1.20 \\
\hline SGS & -0.005 & -1.18 & -0.005 & -1.55 & -0.005 & $-1.48^{* * *}$ \\
\hline $\mathrm{IO}$ & -0.304 & $-1.72^{* * *}$ & -0.005 & -0.02 & 0.048 & 0.16 \\
\hline LEV & -0.086 & $-3.04^{*}$ & -0.017 & -0.94 & -0.014 & -0.79 \\
\hline LnTA & 0.599 & $14.47^{*}$ & 0.364 & $9.02^{*}$ & 0.330 & $7.81^{*}$ \\
\hline Const. & -8.159 & -11.66 & -4.478 & -5.35 & -3.856 & -4.38 \\
\hline Adj. $R^{2}$ & \multicolumn{2}{|c|}{0.435} & \multicolumn{2}{|c|}{0.495} & \multicolumn{2}{|c|}{0.484} \\
\hline F/Wals (p-value) & \multicolumn{2}{|c|}{$43.18(0.000)$} & \multicolumn{2}{|c|}{$90.80(0.000)$} & \multicolumn{2}{|c|}{$9.88(0.000)$} \\
\hline L-M test & \multicolumn{4}{|c|}{$941.27(0.000)$} & & \\
\hline Hausman test & & & \multicolumn{4}{|c|}{$12.36(0.0894)$} \\
\hline
\end{tabular}

Source: Data Analysis Output (Stata 15)

First is the determination of the estimates upon which the study is based. There are three models (pooled, fixed, and random effects), each with its estimates. The L-M test assists in comparing the pooled and random effects, while the Hausman test compares fixed and random effects. Specifically, 
while the L-M test $(941.27 ; \mathrm{p}<0.05)$ indicates support for random effects, the Hausman test $(12.36$; $p>0.05$ ) supports random effects but also may be interpreted as being in support of fixed effects (12.36; $\mathrm{p}<0.1)$. Therefore, both the fixed and random effects are valid estimates for this study. Though, both have closely similar results.

The adjusted $\mathrm{R}^{2}$ is $50 \%$ ( $48 \%$ for fixed effects) indicating that $50 \%$ of changes in industry specialization are influenced by the totality of the explanatory variables as contained in this paper. The Wald chi² value is 90.80; $p>0.05$ (9.88; $p>0.05$ F-statistic for fixed effects), being significant at $5 \%$ level, showing that, the models are adequate and correctly specified. As regards individual explanatory variables, the board size, board independence, proportion of female directors on board, institutional ownership, and leverage displayed negative influence on industry specialization while the size of the audit committee and firm size exhibit a positive relationship. However, only that of board independence $(-0.005 ; \mathrm{p}<0.1)$ and firm size $(0.364 ; \mathrm{p}<0.05)$ are statistically significant with the proportion of female directors on the board $(-0.005 ; \mathrm{p}<0.05)$ added under fixed effects.

\subsection{Diagnostics Tests}

Table 7 shows the results of the heteroscedasticity tests computed.

Table 7. Heteroscedasticity Tests

\begin{tabular}{cc}
\hline \multicolumn{2}{c}{ Bresch-Pagan/ Cook-Weisberg Test for Heteroscedasticity } \\
\hline Ho & Constant variance \\
\hline Variables: & Fitted values of lnIS \\
\hline $\mathrm{Chi}^{2}(1)$ & 109.86 \\
\hline Prob> $\mathrm{Chi}^{2}$ & 0.0000 \\
\hline & White Test for Heteroscedasticity \\
\hline $\mathrm{Ho}$ & \multicolumn{2}{c}{ Homoscedasticity } \\
\hline $\mathrm{Hi}$ & Unrestricted Heteroscedasticity \\
\hline $\mathrm{Chi}^{2}(34)$ & 223.06 \\
\hline${\text { Prob }>\mathrm{Chi}^{2}}$ & Source: Data Analysis Output (Stata 15) \\
\hline
\end{tabular}

Both Bresch-Pagan/ Cook-Weisberg and White Tests indicate the presence of heteroscedasticity. To surmount this, the robust multivariate regression analyses for pooled, fixed, and random effects OLS was computed. The estimates are as presented in table 8.

Table 8. Multivariate Regression Results for Pooled, Fixed and Random Effects OLS (Robust)

\begin{tabular}{ccccccc}
\hline Variables & \multicolumn{2}{c}{ Pooled } & \multicolumn{2}{c}{ Random } & \multicolumn{2}{c}{ Fixed } \\
\hline DV=lnIS & Coef. & t-value & Coef. & z-value & Coef. & t-value \\
\hline BS & 0.177 & 0.73 & -0.011 & -0.50 & -0.018 & -0.73 \\
\hline BI & -0.005 & $-1.89^{* * *}$ & -0.005 & $-2.48^{* *}$ & -0.005 & $-2.41^{* *}$ \\
\hline SAC & 0.079 & 1.02 & 0.104 & 0.86 & 0.097 & 0.76 \\
\hline SGS & -0.005 & -1.22 & -0.005 & -1.22 & -0.005 & -1.17 \\
\hline IO & -0.304 & -1.23 & -0.005 & -0.02 & 0.048 & 0.64 \\
\hline LEV & -0.086 & $-4.80^{*}$ & -0.017 & -0.92 & -0.014 & -0.75 \\
\hline LnTA & 0.599 & $12.70^{*}$ & 0.364 & $7.70^{*}$ & 0.330 & $5.03^{*}$ \\
\hline Const. & -8.159 & -9.02 & -4.478 & -4.42 & -3.856 & -3.14 \\
\hline$R^{2}$ & \multicolumn{2}{c}{0.445} & 0.495 & & 0.484 \\
\hline F/Wals (p-value) & $56.65(0.000)$ & $87.68(0.000)$ & $8.64(0.000)$ \\
\hline
\end{tabular}

Source: Data Analysis Output (Stata 15)

The results as shown in table 8 clearly show one of the great advantages of panel data as it has both time and cross-sectional dimensions. This is evidenced in the estimates as they appear not to be 
significantly different from the non-robust estimates, alongside adjusted coefficient of determinations and number of statistically significant variables. While that of random effect mirrors that given in table 6 , the proportion of female directors on the board $(-0.005 ; \mathrm{p}>0.05)$ is dropped as in the case of fixed bringing the results mimicking each other. However, errors are greatly reduced.

\section{Discussion of Findings}

While the findings from this study appear to be consistent with previous scholarly works, there are notable inconsistencies, as well. First, it is noteworthy to state that estimates from both fixed and random effects are valid, depending upon their p-values which fall within acceptance regions of 0.05 and 0.01 respectively. Consequently, board independence and the proportion of the female gender are inversely and significantly related to the engagement of industry specialists. This is in addition to firm size (though a control variable) that exhibited a positive and significant association with audit quality.

The presence of independent, non-executive directors on boards of entities, is consistent with findings from Nigerian studies such as Ogoun \& Perelayefa (2020), Soyemi, et. al., (2019), and Ejeagbasi, et. al., (2015). These studies adopted audit fees, audit report lag, and big4/non-big4 as proxies for audit quality respectively. Besides, a few others conducted from other jurisdictions reported similar results to include Chintrakarn, et. al. (2017) in the US and Khalil \& Ozkan (2016) within the Egyptian context. This position can be justified on the premise of agency theory that maintains that as a result of the separation between ownership and management, management tends to pursue their objectives which typically contradict that of shareholders. Nevertheless, there are inconsistencies with studies conducted by Soyemi (2020), Sarhan, et. al., (2019), Ghafran \& O'Sullivan (2017), Soliman \& Abdel Salam (2013). While Soyemi (2020) and Soliman \& Abdel Salam (2013) are studies conducted within Nigerian and Egyptian contexts, Sarhan, et. al., (2019) involve the Middle East and North African (MENA) countries of Egypt, Jordan, Oman, Saudi Arabia, and United Arab Emirates (UAE). These studies found a positive and significant relationship between board independence and audit quality. However, Saidu, \& Aifuwa (2020) and Widani \& Bernawati (2020) reported no significant relationship on audit quality.

Recently, the need to appoint female directors on the supervisory board of directors became trendy, hence attracting scholars' attention (Lai, Srinidhi, Gul \& Tsui, 2017). This study found a negative and significant influence of female directors on the engagement of industry specialist auditors, hence audit quality. Though a rare position evidenced in pieces of literature (Lai, et. al., 2017) except as reported by Bhuiyan, Rahman \& Sultana (2020) who reports a negation of positive impact of female directors whose image is tainted. No doubt, this may be a pointer for further research, especially within the Nigerian context. These findings contradict that from studies such as Quick, et. al. (2018), Mustafa, et. al., (2017) and Lai, et. al. (2017). While audit quality was measured with the choice of auditors in the former, audit fees and industry specialization (similar to the present study) are proxies adopted by the latter to whom gender diversity was positive and significantly related.

Regarding control variables, this study also included capital structure (leverage) and size (total assets) of firms in the model specified for estimation. Only firm size exhibited a positive and significant association with audit quality. There seem to be consensus on this area as many previous studies tend to report similar findings with an abysmal few reporting a contrary view. These include Ogoun \& Perelayefa (2020), Soyemi (2020), Sarhan et al (2019), Khudhair et al (2019), Ghafran \& O'Sullivan (2017), Suryanto et al (2017) and Gajevszky (2014) to mention a few. This trend is not surprising as audit engagement is largely documented to have been related to size, complexity, and risk [Soyemi (2015a), Soyemi (2015b), Kikhia (2015)]. However, there were inconsistencies as reported in a study by Quick, et al (2018).

\section{Conclusions}

The study examined the effect of corporate governance practices on audit quality, proxied with industry specialization among quoted non-financial firms in Nigeria. The study revealed that the engagement of industry specialist auditors is negatively influenced by board independence and the 
proportion of female directors on board but positively influenced by the size of the firm. No doubt, this paper has provided further empirical evidence towards understanding the nexus between audit quality and corporate governance practices, thereby contributing to extant kinds of literature, especially for developing economies. Besides, these findings have theoretical and practical implications. The agency theory is the underlying theory for this study. It proposes the existence of information asymmetry owing to separation between management and shareholders, hence, tactically recommends the engagement of tools and techniques (for example, audit) to reduce the incidence of information asymmetry. While findings from this study appear to be inconsistent with agency theory, plausible evidence is provided in support of the hypothesis that individual firms choose their ideal board composition depending upon varying mechanisms adopted in managing their agency conflict.

However, there are a few limitations that may hinder the overt generalizations of findings therein. These may also indicate the direction for future studies in this area. First, the proxy adapted to measure audit quality, that is, industry specialization. This is a rare measure, unlike audit fees and big4 versus non-big4 auditor-type, which is often used in extant literature. This paper appears to be one of the few that is adopting such measures, especially in emerging economies like Nigeria. Second, the Nigerian context is characterized by an emerging corporate governance landscape, the existence of low appointment of female gender into corporate boards, high family-tied corporations (despite public quotations), and low litigation risk for auditors. Lastly, the attendant limitations associated with estimation techniques adopted herein, though efforts were made to surmount a few, a total absence may not be possible.

Author Contributions: All the authors contributed equally to the paper.

Funding: This research received no external funding.

Conflicts of Interest: The authors declare no conflict of interest.

\section{References}

Akhidime, A. (2015). Board structure, corporate characteristics, and audit quality of Nigerian banks. International Journal of Economics, Commerce and Management, 3(6), 832-846.

Al-Qadasi, A. \& Abidin, S. (2018). The effectiveness of internal corporate governance and audit quality: the role of ownership concentration-Malaysian evidence. Corporate Governance, 18(2), 233-253. https://doi.org/10.1108/CG-02-2017-0043

Aribaba, F. O. \& Ahmodu, L. O. (2017) Corporate governance and audit quality of quoted non-financial firms in Nigeria. CARD International Journal of Social Sciences and Conflict Management, 2(4), 30-47.

Asiriuwa, O., Aronmwan, E. J., Uwuigbe, U. \& Uwuigbe, O. R. (2018). Audit committee attributes and audit quality: A benchmark analysis. Business: Theory and Practice, 19, 37-48.

Badawy, H and Aly, A. (2018) The impact of auditor industry specialization, type of auditor and audit opinion on ARL: The Case of Egypt. International Journal of Accounting Research, 6(2), 184-192.

Beisland, L. A., Mersland, R. \& Strøm, R. Ø. (2015). Audit quality and corporate governance: Evidence from the microfinance industry. International Journal of Auditing, 19(3), 218-237.

Bhuiyan, M. B. U., Rahman, A. \& Sultana, N. (2020). Female tainted directors, financial reporting quality, and audit fees. Journal of Contemporary Accounting \& Economics, 16(2), 100189.

Chintrakarn, P., Treepongkaruna, S., Jiraporn, P. \& Tong, S. (2017). Does board independence substitute for external audit quality? Evidence from an exogenous regulatory shock. Evidence from an Exogenous Regulatory Shock (April 28).

Chukwunedu, O. S. \& Ogochukwu, O. G. (2014). Board effectiveness and audit quality in Nigeria: A prospective study. International Journal of Management Sciences, 2(9), 406-417.

Christensen, B. E., Glover, S. M., Omer, T. C. \& Shelley, M. K. (2016). Understanding audit quality: Insights from audit professionals and investors. Contemporary Accounting Research, 33(4), 1648-1684.

Drogalas, G., Arampatzis, K. \& Anagnostopoulou, E. (2016). The relationship between corporate governance, internal audit and audit committee: Empirical evidence from Greece. Corporate Ownership and Control, 14(1), $569-577$. 
Dresdner, H., \& Fischer, D. (2020) Definitions and determinants of audit quality. Journal of Corporate Accounting $\mathcal{E}$ Finance. 31, 197-201.

Eldeeb, M. S. \& Hegazy, M. A. (2016). The impact of auditor industry specialization on the retention and growth of audit clients. Accounting though Journal. 1(20), ISSN: 2356-8402. https://ssrn.com/abstract=3325528

Ejeagbasi, G. E., Nweze, A. U., Ezeh, E. C. \& Nze, D. O. (2015). Corporate governance and audit quality in Nigeria: Evidence from the banking industry. European Journal of Accounting, Auditing \& Finance Research, 5(1), 18-39.

Gajevszky, A. (2014). Audit quality and corporate governance: Evidence from the Bucharest Stock Exchange. Journal of economic and social development, 1(2), 1-11.

Ghafran, C. \& O'Sullivan, N. (2017). The impact of audit committee expertise on audit quality: Evidence from UK audit fees. The British Accounting Review, 49(6), 578-593.

Gana, M. \& Lajmi, A. (2011). Directors' board characteristics and audit quality: Evidence from Belgium. Journal of Modern Accounting and Auditing, 7(7), 668-681.

He, X., Pittman, J. \& Rui, O. M. (2013). Reputational implications for partners after a major audit failure: Evidence from China. Journal of Business Ethics, 138(4), 703-722.

Khalil, M. \& Ozkan, A. (2016). Board independence, audit quality, and earnings management: Evidence from Egypt. Journal of Emerging Market Finance, 15(1), 84-118.

Khudhair, D., Al-Zubaidi, F. \& Raji, A. (2019). The effect of board characteristics and audit committee characteristics on audit quality. Management Science Letters, 9(2), 271-282.

Kikhia, H. Y. (2015). Determinants of audit fees: Evidence from Jordan. Accounting and Finance Research, 4(1), 4253.

Lai, K. M., Srinidhi, B., Gul, F. A. \& Tsui, J. S. (2017). Board gender diversity, auditor fees, and auditor choice. Contemporary Accounting Research, 34(3), 1681-1714.

Mustafa, A. S., Che-Ahmad, A. \& Chandren, S. (2017). Board diversity and audit quality: Evidence from Turkey. Journal of Advanced Research in Business and Management Studies, 6(1), 50-60.

Mustapha, U. A., Rashid, N. N. M., Lateef, S. A. \& Bala, A. (2019). The effect of corporate governance attributes on audit quality in Nigeria. International Journal of Recent Technology and Engineering (IJRTE), 8(4), 4882-4886.

Nasrudin, W. A. W., Mohamed, N. \& Shafie, N. A. (2017). Corporate governance and auditor choice in Malaysia. In SHS Web of Conferences, 36, p. 00007. EDP Sciences.

Ogoun, S. \& Perelayefa, O. G. (2020). Corporate governance and audit quality in Nigeria. American Journal of Industrial and Business Management, 10(2), 250-261.

Piot, C. (2013). Agency costs and audit quality: Evidence from France. European Accounting Review, 10(3), 461-499.

Quick, R., Schenk, N., Schmidt, F. \& Towara, T. (2018). The impact of corporate governance on auditor choice: Evidence from Germany. Journal of Management and Governance, 22(2), 251-283.

Riguen, R., Kachouri, M., \& Jarboui, A. (2018). Book-tax differences, corporate governance effectiveness, and audit quality: An interactive effects. Journal of Corporate Accounting E Finance, 29(4), 20-36

Saidu, M., \& Aifuwa, H. O. (2020). Board characteristics and audit quality: The moderating role of gender diversity. International Journal of Business \& Law Research, 8(1), 144-155.

Salehi, M., Moradi, M., \& Paiydarmanesh, N. (2017). The effect of corporate governance and audit quality on disclosure quality: Evidence from Tehran stock exchange. Periodica Polytechnica Social and Management Sciences, 25(1), 32-48.

Sarhan, A. A. Ntim, C. G. \& Al-Najjar, B. (2019). Antecedents of audit quality in MENA countries: The effect of firm-and country-level governance quality. Journal of International Accounting, Auditing, and Taxation, 35, 85107.

Sari, D. K. (2018). Audit specialization and audit quality: The role of client's business strategy. KnE Social Sciences, 144-172.

Shan, Y. G. (2014). The impact of internal governance mechanisms on audit quality: A study of large listed companies in China. International Journal of Accounting, Auditing and Performance Evaluation, 10(1), 68-90.

Soliman, M. \& Abdel S. M. (2013). Corporate governance practices and audit quality: An empirical study of the listed companies in Egypt. https://dx.doi.org/10.2139/ssrn.2257815.

Soyemi, K. A. (2020). Internal corporate governance practices and choice of the external auditor in Nigeria: A logistic regression analysis. Binus Business Review. 11(1) 9-16. 
Soyemi, K. A., Olabisi, J. \& Akintoye, I. R. (2017). Determinants of external auditor quality among quoted Deposit Money Banks (DMBs) in Nigeria. UNIOSUN International Journal of Business Administration (UIJBA), 1(2), 8399.

Soyemi, K. A., Olufemi, O. A. \& Adeyemi, S. B. (2020). External audit(or) quality and accrual earnings management: Further evidence from Nigeria. Malaysian Management Journal, 24, 31-56.

Soyemi, K. A., Sanyaolu, W. A. \& Salawu, R. O. (2019). Corporate governance practices and external auditors' reporting lag in Nigeria. Accounting \& Taxation Review, 3(4), 15-31.

Srinidhi, B. N., He, S. \& Firth, M. (2014). The effect of governance on specialist auditor choice and audit fees in US family firms. The Accounting Review, 89(6), 2297-2329.

Suryanto, T., Thalassinos, J. E., \& Thalassinos, E. I. (2017). Board characteristics, audit committee, and audit quality: The case of Indonesia. International Journal of Economics and Business Administration, 5(3), 44-57.

Wisdom, O., Love, O. U., Oyedeji, L. Q., Eluyela, D. F. \& Elizabeth, O. K. (2018) Auditors' choice and financing decision of selected quoted firms in Nigeria. International Journal of Management, Accounting E Economics, $5(2), 66-77$.

Widani, N. A., \& Bernawati, Y. (2020). Effectiveness of corporate governance and audit quality: The role of ownership concentration as moderation. Jurnal Etikonomi, 19(1), 131-140.

(C) 2020 by the authors. This article is an open-access article distributed under the terms and conditions of the Creative Commons Attribution (CC BY) license (http://creativecommons.org/licenses/by/4.0/). 